\title{
İşbirlikli Problem Çözme Öğretim Programına Yönelik Öğrenci Görüşleri Kapsamında Bir İhtiyaç Analizi
}

\section{Gülçin Karakuş ${ }^{1}$}

\section{Gürbüz Ocak²}

Type/Tür:

Research/Araştırma

Received/Geliş Tarihi: March

20/ 20 Mart 2020

Accepted/Kabul Tarihi:

November 10/ 10 Kasım 2020

Page numbers/Sayfa No: 1243 -

1266

Corresponding

Author/İletişimden Sorumlu

Yazar: karakusgulcin@gmail.com

\section{$\checkmark$ iThenticate}

This paper was checked for plagiarism using iThenticate during the preview process and before publication. / Bu çalışma ön inceleme sürecinde ve yayımlanmadan önce iThenticate yazılımı ile taranmıştır.

Copyright $@ 2017$ by Cumhuriyet University, Faculty of Education. All rights reserved.

\section{Öz}

$\mathrm{Bu}$ çalışmanın amacı işbirlikli problem çözme öğretim programına yönelik olarak öğrenci görüşlerini inceleyen bir ihtiyaç analizi yapmaktır. Bu amaçla öğrencilerin görüşleri incelenmiştir. Modern eğitim ortamında son dönemlerde yer alan işbirlikli problem çözme becerisine yönelik öğrenci görüşleri çalışmanın odak noktasını oluşturmuştur. Araştırma nitel araştırma deseni kapsamında yapılmıştır. Çalışmada görüşleri alınan katılımcılar amaçlı olarak belirlenmiştir. İşbirlikli problem çözme öğretim programına yönelik öğrenci görüşlerinin belirlenmesi için on açık uçlu sorudan oluşan Yarı Yapılandırılmış Öğrenci Görüşme Formu hazırlanmıştır. Formun oluşturulma sürecinde alan yazın taraması yapılmış ve uzman görüşü alınmıştır. Uzman görüşü ile formda yer alan sorularda gerekli düzeltmeler yapılarak forma son şekli verilmiştir. Çalışmada 4., 5. ve 6. sınıfta öğrenim gören toplan 50 öğrencinin görüşü alınmıştır. Katılımcı görüşleri içerik analizi ile analiz edilmiştir. Elde edilen veriler kodlandiktan sonra temalara ve kategorilere ulaşılmıştır. Kodlar ve temalar düzenlenerek frekans ve yüzdeleri oluşturularak bulgular tanımlanmıştır. Miles ve Huberman'ın (1994) önerdiği güvenirlik formülü kullanılmış ve güvenirlik için önerilen uyum puanı \%89 olarak hesaplanmıştır. Uyuşmanın \% 70'den fazla olması nedeniyle kod ve temaların belirlenmesinde kabul edilebilir bir uyuşma olduğu sonucuna ulaşılmıştır. Çalışma sonucunda öğrencilerin işbirlikli problem çözme kapsamında sosyal problem algılarının sınırlı olduğu, işbirlikli öğrenme gruplarında problem çözmekten ve birlikte çalışmaktan mutlu oldukları ve grup içi ortak anlayışa önem verdikleri sonucuna ulaşılmıştır.

Anahtar Kelimeler: İşbirlikli problem çözme, öğrenci görüşü, ihtiyaç analizi, işbirlikli öğrenme, problem çözme.

\footnotetext{
Suggested APA Citation/Önerilen APA Atıf Biçimi:

Karakus, G. \& Ocak, G. (2020). İşbirlikli problem çözme öğretim programına yönelik öğrenci görüşleri kapsamında bir ihtiyaç analizi. Cumhuriyet International Journal of Education, 9(4), 1243-1266. http://dx.doi.org/10.30703/cije.707035
}

\footnotetext{
Bu çalışma İşbirlikli Problem Çözme Öğretim Programı Tasarısının Hazırlanması ve Uygulanması isimli doktora tezinden üretilmiştir.

${ }^{1}$ Öğretmen, Sivas Mustafa Kemal Atatürk Mesleki ve Teknik Anadolu Lisesi , Sivas/Türkiye Teacher, Sivas Mustafa Kemal Atatürk Vocational and Technical High School, Sivas/Turkey e-mail: karakusgulcin@gmail.com ORCID ID: orcid.org/ 0000-0002-0587-4079

${ }^{2}$ Prof. Dr. , Afyon Kocatepe Üniversitesi, Eğitim Fakültesi, Eğitim Bilimleri Bölümü, Eğitim Programları ve Öğretimi Anabilim Dalı, Afyon/Türkiye

Prof. Dr. Afyon Kocatepe University, Education Faculty, Department of Curriculum and Teaching, Afyon / Turkey e-mail: gocak@aku.edu.tr.ORCID ID: orcid.org/0000-0001-8568-0364
} 


\title{
A Needs Analysis to Investigate Students' Views About Cooperative Problem Solving Curriculum
}

\begin{abstract}
The aim of this study is to investigate students' views about cooperative problem solving to suggest a needs analysis for cooperative problem solving curriculum. The study was conducted as a qualitative study. Students' views on collaborative problem solving skills, which have an important place in the modern education environment, have been the focus of the study. Semi-Structured Student Interview Form was prepared. During the creation of the form, literature review was made and expert opinion was asked. With the expert opinion, the necessary final changes were made on the questions in the student form, and the form was finalized. Form consists of ten open-ended questions. The sample consists of totally 50 students from 4th, 5th and 6th grades. Content analysis method was used to analyze the data. First the data was coded, then themes and categories were determined. For the reliability of the study, Miles and Huberman's (1994) formula was used and it was calculated as \% 89. As a result of the study, it is determined that students have limited understanding about social problems, they enjoy solving problems in cooperative groups with their friends and they pay attention to have a common understanding in groups while solving problems cooperatively.
\end{abstract}

Keywords: Cooperative problem solving, student view, needs analysis, cooperative learning, problem solving.

\section{Giriş}

Eğitim ortamında ihtiyaç eğitsel olarak bir boşluğun ya da eksikliğin olduğunu ifade etmektedir, istenilen duruma ulaşmak için gerekli görülen anlayış, tavır ve becerileri kapsamaktadır (Atwood ve Ellis, 1971). İhtiyaç analizi genel olarak bilgi toplama, bilgileri analiz etme ve program oluşturma aşamalarından oluşmaktadır. Adıgüzel (2016) ihtiyaç analizinde ilk aşamanın konunun kapsamının ve özelliklerinin belirlenmesi olduğunu, ikinci aşamanın hedef kitlenin belirlenmesi olduğunu, üçüncü aşamada yer tespitinin yapılması gerektiğini ve son olarak da zamanın belirlenmesi gerektiğini ifade etmektedir. Bu bağlamda son y1llarda yeni bir kavram olarak kullanılan işbirlikli problem çözme ile ilgili öğrencilerin ne kadar bilgi sahibi olduklarının belirlenmesi, işbirlikli problem çözmeye dair bir ihtiyaç analizi çalışmasının yapılması bu doğrultuda önemlidir. Arsal (1998) ihtiyaç analiz kaynaklarından biri olan bireyin psikolojik, sosyal ve eğitim ihtiyaçlarının, bireyin ilgi ve yeteneğinin önemli olduğunu belirtmektedir. Mc Cawley (2009) ise ihtiyaç analizini hedef kitlenin belirli bir konudaki bilgi, beceri, ilgi ya da tutumuna yönelik durumunun belirlenmesi olarak tanımlamaktadır. İhtiyaç analizi bir öğretim programının daha etkili, daha kullanışlı ve daha uygulanabilir olmasını sağlamaktadır. Bunun nedeni ihtiyaç analizi ile araştırmacı aldığı kararların temel nedenini belirler ve daha kararlıdır, var olan durum ile istenen durum arasında bağ kurulmasını sağlar. Mc Cawley (2009) ihtiyaç analiz basamaklarını şu şekilde sıralamaktadır; amacın belirlenmesi, hedef kitlenin tespit edilmesi, örneklemin seçilmesi, veri toplama aracının belirlenmesi, verilerin toplanması ve verilerin analiz edilmesi.

Program geliştirmenin temel varsayımlarından biri programın ihtiyaç analizine dayalı olarak hazırlanmasıdır. Bu analiz programa yönelik ihtiyacı belirlemek amacıyla sistematik veri toplama süreci olarak da nitelendirilebilir (Richards, 2001). İhtiyaç analizi bir problem durumunun tespit edilmesi ile başlar ve bu probleme bağlı 
olarak ihtiyacı araştırır. Daha sonra ise elde edilen bilgiler ışı ğında hazırlanacak olan programın hedef, içerik, eğitim durumu ve değerlendirme sürecine 1şık tutar (Azimi ve Rahmani, 2003). İhtiyaç analizi yapılmadan hazırlanan bir programda uyuşmazlıklar olabilir. Bu uyuşmazlık öğrencinin öğrenmesi beklenen bilgi ve beceri ile öğrencinin öğrendiği bilgi ve becerileri kapsar (Watanabe, 2006).

$\mathrm{Bu}$ bağlamda bu çalışmada işbirlikli problem çözme öğretim programının hazırlanması için ilk aşama olarak ihtiyaç analizi yapılmıştır. İhtiyaç analizi program geliştirmenin önemli bir aşamasıdır ve öğrencilerin neleri öğrenmesi gerektiğinin önceden tespit edilmesi gerekmektedir (Chegeni ve Chegeni, 2013). İhtiyaç belirleme sürecinde gözlem, görüşme ve anket gibi veri toplama yöntemleri kullanılabilir (Hutchinson ve Waters, 1987, Akt. Bosher ve Smalkoski, 2004) ve pratik uygulamalara ve sonuçlara yönelik olması gerekmektedir. Her ne kadar zaman alıcı ve masraflı olarak düşünülse de program hazırlığında ihtiyaç analizi önemli bir yer tutar. Ayrıca ihtiyaç analizi yapılırken ihtiyaçların çok boyutlu özelliklerinin de dikkate alınması önemlidir (Sava, 2012).

İhtiyaç analizi kapsamında hazırlanacak olan bir işbirlikli problem çözme öğretim programı bireyin sosyalleşmesi ve psikolojik olarak kendini ifade edebilmesi, kendi fikrini savunması gibi yararlarına bağlı olarak öğrencinin eğitim ortamında kendisinden beklenen işbirlikli problem çözme becerisinin gelişimini sağlayacaktır.

Literatürde karşılıklı etkileşim içinde olduğu ifade edilen işbirlikli öğrenme ve problem çözme kavramları birlikte kullanılmalarına imkan veren uygulamalarla ayır çalışmalara oranla başarılı sonuçlara ulaşılabileceğini göstermektedir. Barth ve Demirtaş (1997) işbirlikli öğrenmenin öğrencilerin problem çözme becerilerini geliştirdiğini ifade etmektedir. Ancak ayrı bir kavram olarak işbirlikli problem çözme literatürde yer almaktadır. Wooldridge ve Jennings, (1999) ise işbirlikli problem çözmeyi, bireylerin ortak bir amaca ulaşmak için birlikte çalışma süreci olarak tanımlarken, Graesser, Dowell ve Clewley (2017) işbirlikli problem çözmeyi, bir problemi çözme amacıyla iki ya da daha fazla bireyin bilgi, beceri ve çabalarını bir araya getirme süreci olarak tanımlamaktadır. Bir başka tanımda Fiore, Cuevas, Scielzo ve Salas (2017) işbirlikli problem çözme sürecini bireylerin ortak bir sonuca ulaşmak için bir takım iletişim süreçleri aracılığıyla, kendi kaynaklarını ve stratejilerini kullanmaları olarak ifade etmektedir.

İşbirlikli problem çözme kavramı ilk olarak PISA 2015 raporunda yer almaktadır. PISA her üç yıllık aralıklarla okuma-yazma becerileri, matematik okuryazarlığı ve fen okuryazarlığı gibi temel alanların dışında bir de yenilikçi bir ölçme alanı belirlemektedir. PISA 2003' te yenilikçi ölçme alanı olarak problem çözme becerisini, 2012' de bilgisayar ortamında bireysel problem çözme becerisini ve $2015^{\prime}$ te ise bilgisayar ortamında işbirlikli problem çözme becerilerini vurgulamıştır. PISA' da vurgulanan bu yenilikçi ölçme alanlarının merkezinde problem çözme becerisi yer almaktadır. Bunun yanında PISA'da vurgulanan bir diğer önemli beceri ise öğrencilerin takım çalışmasında verilen bir görevi başarmasıdır. 21. yüzyılda öğretimdeki bir öğrenci profili, araştırma yapabilen, akılc1, sorgulayan, iletişim becerisi güçlü, teknolojiyi etkili ve verimli kullanabilen, problem çözme becerisi yüksek ve grup halinde çalışma (işbirliği yapma) becerisine sahip şeklinde siralanabilir (MEB, 2011).Bu durum işbirlikli problem çözmenin önemini ifade etmektedir. 
PISA 2015 yılı değerlendirme raporunda ülkemizdeki öğrencilerin işbirliğine dayalı problem çözme becerilerinin oldukça düşük seviyede olduğu ifade edilmektedir. Rapor, ülkemizdeki öğrencilerin grup çalışmasını sevmediğini ve ekip olarak verilen bir problemi çözmede oldukça yetersiz olduklarını ifade etmektedir. Buna karşın rapora göre işbirlikli problem çözmede örneğin Singapur'daki öğrencilerin diğer tüm katılımcı ülkelerdeki öğrencilerden daha yüksek puan aldığı, Japonya' nın ise bu sıralamada ikinci sırada olduğu belirtilmektedir. OECD ülkelerinde ortalama olarak, öğrencilerin sadece \% 28'i eğer varsa basit işbirlikli problemleri çözebilmektedir. Ancak Estonya, Hong Kong (Çin), Japonya, Kore, Makao (Çin) ve Singapur'da altı öğrenci arasında birden daha azı işbirlikli problem çözmede düşük bir başarı göstermektedir. OECD ülkeleri genelinde, öğrencilerin \% 8'i işbirlikli problem çözmede en iyi performansı göstermektedir. Diğer ülkeler ile karşılaştırıldığında bu durum bu ülkelerdeki öğrencilerin grup dinamiklerinin farkında olduklarını, takım ruhunu benimsediklerini ve buna uygun hareket ettiklerini göstermektedir (OECD, 2017). Ülkemizin PISA vb. sinavlarda yer alması önemlidir ancak öğretim ve uygulama olarak etkili eğitim sistemlerini temsil eden bir yapının ülkemizde bu alanda yapılan faaliyetlerle ne derece örtüştüğünün de düşünülmesi gerekmektedir. PISA' da amaç okul bilgilerinin gündelik hayata nasıl transfer edildiği ve aradaki bağın nasıl kurulduğunu incelemektir. Ülkemizde de uygulanan öğretim ve değerlendirmenin bu amaçla örtüşmesi tüm çabanın bilimsel geçerliliğini sağlayacaktır (Çepni, 2016). Öğrencilerin işbirlikli problem çözme becerisi kazanmaları, bu beceri ile diğer ülkeler arasında yer almaları önemli olarak görülmektedir. Dolayısıyla ülkemizin işbirlikli problem çözme becerisinin geliştirilmesine yönelik hazırlanacak bir işbirlikli problem çözme öğretim programına yönelik öğrenci görüşlerini kapsayan bir ihtiyaç analizi çalışmasının yapılması önemlidir.

\section{Problem Cümlesi}

İşbirlikli problem çözmeye yönelik öğrenci görüşleri nelerdir?

\section{Alt Problemler}

1. Öğrencilerin problemin tanımına yönelik görüşleri nelerdir?

2. Öğrencilerin problem çözmeye yönelik görüşleri nelerdir?

3. Öğrencilerin bireysel ve grupla problem çözmeye yönelik görüşleri nelerdir?

4. Öğrencilerin işbirlikli problem çözme sürecinde ne yapıldığına dair görüşleri nelerdir?

5. İşbirlikli problem çözme sürecine yönelik öğrencilerin tutumları nasıldır?

6. Öğrencilerin işbirlikli problem çözme sürecinde arkadaşının görüşü ile ilgili düşünceleri nelerdir?

7. Öğrencilerin grup içinde baskın olan arkadaşlarının işbirlikli problem çözme süreci üzerindeki etkisi ile ilgili görüşleri nelerdir?

8. Öğrencilerin işbirlikli problem çözme sürecinde karşılaşabilecekleri fikir uyuşmazlığını çözmeye yönelik görüşleri nelerdir? 


\section{Yöntem}

$\mathrm{Bu}$ çalışma öğrenci görüşlerini inceleyen bir nitel araştırmadır. Nitel araştırma katılımcının olaylarla ilgili olarak öznel bakış açılarının keşfedilmesini sağlamaktadır (Storey, 2007). Ayrıca nitel araştırma doküman analizi, gözlem ve görüşme gibi tekniklerle verinin toplandığı, olayların doğal ortamda bütüncül bir yapıda incelendiği bir araştırma sürecidir (Yıldırım ve Şimşek, 2003).

Çalışmada ihtiyaç belirleme yaklaşımı olarak analitik yaklaşım benimsenmiştir. Analitik yaklaşım ile ulusal ve uluslararası koşullara dayalı değişimlere ait yönelimler dikkatle incelenir. Gelecekte ortaya çıkması muhtemel durumlardan yola çıkarak eğitim ihtiyaçları belirlenir (Gözütok, 1994).Bu bağlamda bu çalışmada öğrencilerin işbirlikli problem çözme ile ilgili gelecekte yapılacak uygulamalara dair görüşleri dikkate alınmıştır.

\section{Çalışma Grubu}

Çalışma grubu 50 öğrenciden oluşmaktadır. Çalışma grubu amaçlı olarak belirlenmiştir. Araştırmacının amacı sınırlı kaynağın en etkin şekilde kullanımı için bilgi bakımından zengin yapıların belirlenmesi ve seçilmesidir (Patton, 2002). Bernard (2002) ve Spradley (1979) katılımın uygunluğunun, istekliliğin ve deneyimlerin fikir verici özellikte olması gerektiğinin önemine vurgular. Çalışmaya katılımda gönüllülük esası dikkate alınmıştır. Öğrencilerin öğrenim gördüğü okul sosyoekonomik düzeyi orta seviyede olan bir okuldur. Öğrencilerin derslerinde grup çalışmalarına ve problem çözme etkinliklerine katılımları çalışma grubunun belirlenmesi sürecinde dikkate alınmıştır. Çalışmaya dördüncü sınıfta öğrenim gören 12 öğrenci, beşinci sınıfta öğrenim gören 16 öğrenci ve altıncı sınıfta öğrenim gören 22 öğrenci katılmıştır. Katılımcılara S1, S2, S3 şeklinde kodlar verilmiştir.

\section{Verilerin Toplanması}

Öğrenci görüşmelerinde sorular yarı yapılandırılmış görüşme tekniğine uygun olarak ve bire bir yöneltilmiştir. Görüşmeler görüşülenlerin izni alınarak ses kayıt cihazı ile kaydedilmiştir. Görüşme esnasında katılımcıları yönlendirmemek amacıyla jest ve mimiklerden kaçınılmıştır. Öğrenciler ile yapılan görüşmeler ortalama 10'ar dakika sürmüştür.

\section{Veri Toplama Araçları}

Çalışmada veri toplama aracı olarak on açık uçlu sorudan oluşan yarı yapılandırılmış görüşme formları hazırlanmıştır. Yarı yapılandırılmış görüşme formunda tüm katılımcılara aynı sorular aynı ifadelerle ve aynı sırada sorulmuştur ve sorular belirgin sorulardır (Corbetta, 2003). Bu tür formlarda araştırmacı hem konuyu hem de görüşmeyi kontrol edebilmektedir. Görüşme formunda işbirlikli problem çözme öğretim programının temel unsurları alanlarında sorular hazırlanmış ve hazırlanan taslak formun anlaşılabilirliğinin belirlenmesi için bir dil uzmanından uzman görüşü alınmıştır. Uzman görüşünün ardından elde edilen dönütlere göre cümlelerde dilbilgisi kapsamında gerekli düzeltmeler yapılarak görüşme formu katılımcılara uygulanmıştır. Son düzeltmeler kapsamında görüşme formunda yer alan sorular şu şekildedir;

1. “Problem nedir? Problem çözmek ne demek?" 
2. "Problem hangi derste ya da derslerde çözülür?"

3. "İşbirliği ne demek? İşbirliği yapmanın yararı nedir?"

4. "Problem çözerken neler yaparsın? Senin görev paylaşımı yapman gerekse işbölümünü nasıl yaparsın?"

5. Bir problemi tek başına mı çözmek daha güzel arkadaşınla birlikte mi çözmek daha güzel? Bir problemi tek başına mı yoksa arkadaşınla mı daha kolay çözersin? Neden?"

6. "Bir problemi çözebilmek için neler yaparsın? Problem çözerken izlediğin bir yol/sıra var mı? Açıklar mısın? Arkadaşlarınla birlikte çalışırken onların fikirlerini önemser misin? Neden? Bir grup olarak problem çözerken arkadaşlar farklı şeyler söylerse ya da yapmak isterse ortak bir noktaya ulaşmak için neler yapılır?"

7. “Bir problemi çözemediğin zaman kime sorarsın? Bir problemi çözemediğinde sadece büyüklerine mi soru sorasın? Yapabileceğin başka bir şey var mi?"

8. "Problem çözmede daha başarılı olmak için neler yapılmalı? Grup olarak çalışırken anlaşmazlık olursa bu durum nasıl çözülür?"

9. “Bilmediğin bir şey olduğunu fark edince onu öğrenmek ister misin? Nasıl öğrenebilirsin?"

10. "Verilen bir problemi çözerken arkadaşınla birlikte çalışırsan ne hissediyorsun? Arkadaşlarından biri her zaman kendi söylediğinin yapılamasinı isterse ne yaparsın?"

\section{Verilerin Analizi}

Katılımcı görüşlerinin analizinde içerik analizi, yöntemi kullanılmıştır. Elde edilen verilerden kodlar elde edilmiş daha sonra temalara ve kategorilere ulaşılmıştır. İçerik analizi, birbirine benzeyen verileri belirli kavramlar ve temalar çerçevesinde bir araya getirmek ve bunları okuyucunun anlayabileceği bir biçimde organize ederek yorumlamak amacıyla yapılmıştır. Betimsel analizde ise elde edilen verilerin daha önceden belirlenmiş temalar çerçevesinde özetlenmiştir. Araştırmacı görüştüğü bireylerin görüşlerini yansıtabilmek amacıyla doğrudan alıntılara sık sık yer vermiştir. $\mathrm{Bu}$ analiz türünde temel amaç elde edilmiş olan bulguların okuyucuya özetlenmiş ve yorumlanmış bir biçimde sunulmasıdır (Yıldırım ve Şimşek, 2006). Geçerlik ve güvenirliğin sağlanması amacıyla araştırmacıların görüş birliği hesaplanmıştır. Bu bağlamda görüşler, iki araştırmacı tarafından ayrı ayrı kodlanmıştır. Daha sonra kodlamalar karşılaştırılmıştır. Aralarında görüş birliği ve görüş ayrılı̆̆ı olan kodlamalar belirlenmiştir. Miles ve Huberman eın (1994) güvenilirlik formülüne [Güvenilirlik = (Görüş birliği / görüş birliği + görüş ayrılı̆̆g] göre güvenilirlik hesaplaması yapılmıştır. Hesaplama sonucunda araştırmanın güvenirliği \% 89 olarak hesaplanmıştır. Güvenirlik hesaplarının \%70'in üzerinde çıkması, araştırma için güvenilir kabul edilmektedir (Miles ve Huberman, 1994). Bu çalışmada elde edilen sonuç, güvenilir kabul edilmiştir.

\section{Bulgular}

Bu bölümde çalışmanın bulguları araştırmanın alt problemlerine göre sunulmuştur. Öğrencilerin probleme yönelik görüşleri nelerdir?

Öğrencilerin probleme yönelik görüşleri Tablo 1'de verilmiştir. 
Tablo 1.

Öğrencilerin Probleme Yönelik Görüşleri

\begin{tabular}{|c|c|c|c|}
\hline \multicolumn{4}{|c|}{ Problem Nedir? } \\
\hline Kategori & Tema & Kod & $\mathrm{f}$ \\
\hline \multirow{4}{*}{ Anlam } & \multirow{2}{*}{$\begin{array}{l}\text { Sosyal } \\
\text { Bağlam }\end{array}$} & Toplumsal sorun: ( S16, S33, S34 ) & 3 \\
\hline & & $\begin{array}{l}\text { Günlük hayatta her zaman karşılaşabileceğimiz sorunlardır:( } \\
\text { S35, S38, S41 ) }\end{array}$ & 3 \\
\hline & \multirow[t]{2}{*}{ Ders İçeriği } & $\begin{array}{l}\text { Problem bir sorudur: ( S10, S11, S15, S16, S25, S28, S40, S47, S48, } \\
\text { S49, S50 ) }\end{array}$ & 11 \\
\hline & & Örneğin ... bir problemdir: ( S5, S6, S7, S8, S44 ) & 5 \\
\hline \multirow{5}{*}{ Etki } & \multirow{3}{*}{$\begin{array}{l}\text { Sonuç } \\
\text { Odaklı }\end{array}$} & $\begin{array}{l}\text { Çözülmesi gereken sorun : ( S1, S2, S3, S4, S9, S12, S14, S19, S20, } \\
\text { S21, S22, S24, S27, S29, S30, S32, S36, S37 ) }\end{array}$ & 18 \\
\hline & & Çözülmesi güç şeydir: ( S42, S43, S23 ) & 3 \\
\hline & & Anlaşmazlıktır: ( S26, S39, S45 ) & 3 \\
\hline & \multirow[t]{2}{*}{ Olumsuzluk } & Sıkıntıdır : (S13, S18, S46 ) & 3 \\
\hline & & Olumsuz bir durumdur: ( S11, S17) & 2 \\
\hline
\end{tabular}

Tablo 1 incelendiğinde öğrencilerin probleme yönelik görüşlerinin anlam ve etki kategorisinde toplandığı görülmektedir. Anlam kategorisi sosyal bağlam ve ders içeriği temalarından, etki kategorisi ise sonuç odaklı ve olumsuzluk temalarından oluşmaktadır. Öğrencilerin problemi en fazla çözülmesi gereken sorun (18) ve soru (11) olarak tanımladıkları görülmektedir. Bazı öğrencilerin problemi toplumsal sorun (3) ve günlük hayatta her zaman karşılaşılabilecek sorunlar(3) olarak tanımladıkları görülmektedir. Bazı öğrencilerin ise örnek verdikleri(5), bazı öğrencilerin ise problemi çözülmesi güç şey (3), anlaşmazlık (3) ve sıkıntı (3) olarak tanımladıkları belirlenmiştir. Az sayıda öğrencinin ise problemi olumsuzluk (2) olarak algıladığı görülmektedir. Bu bulguya yönelik öğrencilerin görüşlerinden örnekler aşağıda sunulmuştur.

S2: "Problem çözülmesi gereken bir sorundur" (Sonuç odaklı teması örnek görüş).

S25: "Problem herhangi bir işlemle sonuca ulaşmamızı sağlayan sorudur "(Ders içeriği teması örnek görüş).

S35: "Problem günlük hayatta karşılaşılan sorunlardır "(Sosyal bağlam teması örnek görüş).

S49: "Problem işlem gerektiren veya matematiksel zekâ gerektiren soru cümlesidir "( Ders içeriği teması örnek görüş).

S26: "Problem anlaşmazlıkla ortaya çıkan sorunlardır"(Olumsuzluk teması örnek görüş).

S42 : "Problem bilimsel yöntemlerle çözülen, çözülmesi güç olan şeydir "( Olumsuzluk teması örnek görüş).

S7: “ Sınavda düşük puan aldığımız zaman üstümüze çok gelinmesi bir problem örneğidir mesela bu bir problemdir "( Ders içeriği teması örnek görüş).

Öğrencilerin problem çözmeye yönelik görüşleri nelerdir?

Öğrencilerin problem çözmeye yönelik görüşleri Tablo 2' de verilmiştir. 
Tablo 2.

Öğrencilerin Problem Çözmeye Yönelik Görüşleri

\begin{tabular}{|c|c|c|c|}
\hline \multicolumn{4}{|c|}{ Problem Çözmek Ne Demektir? } \\
\hline Kategori & Tema & Kod & f \\
\hline \multirow{8}{*}{ Hedef } & \multirow{3}{*}{ Başarı } & $\begin{array}{l}\text { Doğru cevabı bulmaktır: ( S17, S28, S29, S36, S37, S47, } \\
\text { S15, S46, S49, S50, S58 ) }\end{array}$ & 11 \\
\hline & & Sayısal işlem yapmaktır :( S10, S25 ) & 2 \\
\hline & & Problemi anlamaktır :( S1 ) & 1 \\
\hline & \multirow{2}{*}{ Çaba } & Uğraşmaktır: ( S18, S23, S39, S41, S43, S45 ) & 6 \\
\hline & & Anlaşmaktır :( S33, S40 ) & 2 \\
\hline & \multirow{3}{*}{ Refah } & $\begin{array}{l}\text { Sorun çözmektir: ( S3, S4, S5, S6, S7, S12, S16, S19, S20, } \\
\text { S22, S24, S26, S27, S30, S31, S33, S35, S38, S42, S44, S46) }\end{array}$ & 21 \\
\hline & & Sıkıntıyı sonlandırmaktır : $(\mathrm{S} 11, \mathrm{~S} 13, \mathrm{~S} 18)$ & 3 \\
\hline & & Sorunu kendi yolunla çözmektir: ( S9, S21 ) & 2 \\
\hline \multirow{2}{*}{ Diğer } & \multirow{2}{*}{ Nötr } & Cevapsiz ( S32, S48 ) & 2 \\
\hline & & Bilgiyi arttırmaktır :( S14 ) & 1 \\
\hline
\end{tabular}

Tablo 2 incelendiğinde öğrencilerin problem çözmeye yönelik görüşlerinin hedef ve diğer şeklinde iki kategoride toplandığı görülmektedir. Hedef kategorisi başarı, çaba ve refah temalarını, diğer kategorisi ise nötr temasını içermektedir. Öğrenci görüşlerinin en çok refah temasında sorun çözme ifadesinde (21),daha sonra ise başarı temasında doğru cevap (11) ifadesinde yoğunlaştığı görülmektedir. Bazı öğrenciler problem çözmeyi uğraşma (6), bazı öğrenciler ise sıkıntıyı sonlandırma (3) olarak tanımlamaktadırlar. En az ise nötr temasında bilgiyi arttırma ve başarı temasında problemi anlama (1) ifadeleri şeklinde olduğu görülmektedir. Bu bulguya yönelik öğrencilerin görüşlerinden örnekler aşağıda sunulmuştur.

S41: "Problem çözmek bir sorunu nasıl düzeltebileceğini en ince ayrıntısına kadar düşünüp bunu harekete geçirmektir "(Çaba teması örnek görüş).

S47: "Problemi anladıktan sonra verilen veriler aracillğıyla problemin cevabinı bulmaktır" ( Başarı teması örnek görüş).

S37: "Çözümleri tek tek deneyerek ortada olan bir sorunu çözmek demektir "( Başarı teması örnek görüş).

S49: "Problem çz̈zmek soruyu tamamlamak demektir. Sorulan bir soruyu cevaplamak demektir "(Başarı teması örnek görüş).

S34: "Toplum arasında çıkan sorunlar hakkında uzlaşmaktır "(Refah teması örnek görüş).

S1: "Problem çözmek düşünerek bilgilerimizi açıklayarak yaptığımız şeydir "(Başarı teması örnek görüş).

S11 : "Olumsuz davranışları sakin bir biçimde halletmektir. Diğgr anlamda ise matematik dersinde soruları çz̈zmektir" (Refah teması örnek görüş).

Öğrencilerin bireysel ve grupla problem çözmeye yönelik görüşleri nelerdir?

Öğrencilerin bireysel ya da grupla problem çözmeye yönelik görüşleri Tablo $3^{\prime}$ de verilmiştir. 
Tablo 3.

Öğrencilerin Bireysel ve Grupla Problem Çözmeye Yönelik Görüşleri

\begin{tabular}{|c|c|c|}
\hline \multicolumn{3}{|c|}{ Bir problemi tek başına çözmek mi daha güzel, arkadaşlarınla çözmek mi daha eğlenceli? } \\
\hline Tema & Kod & f \\
\hline Birlikte & $\begin{array}{l}\text { Arkadaşlarla çözmek daha güzel : ( S1, S2, S3, S4, S5, S6, S7, S8, } \\
\text { S12, S15, S16, S17, S18, S19, S20, S21, S24, S25, S26, S27, S28, S30, } \\
\text { S31, S32, S33, S34, S35, S36, S37, S38, S43, S44, S45, S48, S49, S50) }\end{array}$ & 36 \\
\hline Tek & $\begin{array}{l}\text { Kendi kendime çözmek daha güzel : ( S9, S10, S11, S13, S14, S22, } \\
\text { S23, S40, S42, S46, S47 ) }\end{array}$ & 11 \\
\hline Nötr & Cevapsiz: ( S29, S41) & 2 \\
\hline \multicolumn{3}{|c|}{ Bir problemi tek başına mı daha kolay çözersin, arkadaşınla mı daha kolay çözersin? } \\
\hline Tema & Kod & f \\
\hline \multirow[t]{4}{*}{ Arkadaş Desteği } & $\begin{array}{l}\text { Arkadaşlarımla daha kolay çözerim, çünkü daha çok fikir olur : ( } \\
\text { S1, S2, S3, S4, S6, S7, S8, S9, S12, S18, S20, S23, S24, S25, S26, S27, } \\
\text { S28, S30, S31, S32, S33, S34, S35, S36, S37, S38, S39, S41, S43, S44, } \\
\text { S45, S48, S49, S50 ) }\end{array}$ & 34 \\
\hline & Arkadaşlarımla, çünkü daha eğlenceli : ( S5, S16, S21) & 3 \\
\hline & İyi anlaştığım arkadaşlarımla daha kolay çözerim : ( S29 ) & 1 \\
\hline & Arkadaşlarımla, çünkü işbirliği yaparız :( S14, S15, S17, S19 ) & 4 \\
\hline \multirow{4}{*}{ Bireysel } & Kendim daha kolay çözerim, çünkü öyle isterim : ( S13, S22 , S42 & 3 \\
\hline & Çünkü fikir ayrıllı̆̆ı yok : ( S10, S40 ) & 2 \\
\hline & Kendim daha kolay çözerim, çünkü farklı fikir istemem : ( S11 ) & 1 \\
\hline & $\begin{array}{l}\text { Kendim daha kolay çözerim, çünkü sessiz ortamda dikkatimi } \\
\text { veririm : ( S47) }\end{array}$ & 1 \\
\hline Problemin Yapisı & Probleme göre değişir : (S46) & 1 \\
\hline
\end{tabular}

Tablo 3 incelendiğinde öğrencilerin bireysel ya da grupla problem çözmeye yönelik görüşlerinin birlikte, tek ve nötr temalarında toplandığı görülmektedir. Eğlence kapsamında görüşlerin en çok birlikte (36), daha sonra tek (11), ve en az ise nötr (2) olarak üç temada toplandığı görülmektedir. Kolay çözme kapsamında ise öğrenci görüşlerinin en çok arkadaş desteği (42), daha sonra bireysel (7) ve en az ise problemin yapısı (1) olarak üç temada toplandığı görülmektedir. Öğrencilerin arkadaşları ile birlikte problem çözmelerinin daha eğlenceli olduğunu ve arkadaşları ile birlikte daha kolay problem çözdüklerini belirttikleri görülmektedir. Bu bulguya yönelik öğrencilerin görüşlerinden örnekler aşağıda sunulmuştur.

S42: "Bir problemi tek başıma çözmek bence daha eğlenceli "(Tek teması örnek görüş).

S49: "Bence bir problemi arkadaşlarımla birlikte çözmek daha eğlencelidir "(Birlikte teması örnek görüş).

S8: “Bence bir problemi arkadaşlarımla birlikte çözmek çok daha eğlenceli, çünkü arkadaşlarımın görüşleriyle birlikte çok daha iyi bir sonuca ulaşırız "(Birlikte teması örnek görüş).

S40: "Ben biraz dik başh bir öğrenci olduğum için kendi kendime çözmek daha eğlenceli " (Tek teması örnek görüş).

S41: "Bence ikisi de eğlenceli, hepsinden de zevk alıyorum "(Nötr teması örnek görüş).

Bir problemi tek başına mı daha kolay çözersin, arkadaşınla mı daha kolay çözersin? 
S47: " Tek başıma çözmek daha kolay çünkü daha çok sessiz ortam isterim ve sadece kendi dikkatimi vererek çözmeyi daha çok severim " (Bireysel teması örnek görüş).

S15: "Arkadaşlarımla birlikte daha kolay çözerim çünkü danışmak çok iyidir "(Arkadaş desteği teması örnek görüş).

S11: "Tek başıma daha kolay çözerim çünkü insanlar benim fikrime karşı fikirler ortaya koyabilir ve ben bu durumdan hoşlanmam "( Bireysel teması örnek görüş).

S16: "Arkadaşlarımla daha kolay çözerim çünkü herkesin yetenek alanı farklı olur. Yani herkes konu hakkında fikir söyler ve uygun olanı seçeriz "(Arkadaş desteği teması örnek görüş).

S7: “Arkadaşlarımla daha kolay çözerim çünkü benim bilmediklerimi arkadaşlarımdan öğrenebilirim "(Arkadaş desteği teması örnek görüş). nelerdir?

Öğrencilerin işbirlikli problem çözme sürecinde ne yapıldığına dair görüşleri

Öğrencilerin işbirlikli problem çözme sürecinde ne yapıldığına dair görüşleri Tablo 4'de verilmiştir.

Tablo 4

Öğrencilerin İşbirlikli Problem Çözme Sürecinde Ne Yapıldığına Dair Görüşleri

\begin{tabular}{|c|c|c|c|}
\hline \multicolumn{4}{|c|}{ Arkadaşın ile problem çözerken neler yaparsın? } \\
\hline Kategori & Tema & Kod & f \\
\hline \multirow{6}{*}{ Grup Etkisi } & \multirow[t]{2}{*}{ Bütünlük } & $\begin{array}{l}\text { Ortak bir fikir bulmaya çalışırız : ( S4, S8, S9, S10, } \\
\text { S11,S14, S19, S23, S29, S32, S42, S44, S45, S48 ) }\end{array}$ & 14 \\
\hline & & Bildiklerimizi birleştiririz: ( S2, S7, S16, S27, S28, S35 ) & 6 \\
\hline & \multirow{4}{*}{ Eşitlik } & S1rayla fikirlerimizi söyleriz : ( S1, S21, S25, S37, S41 ) & 5 \\
\hline & & Tartışırız : (S3, S5, S6, S12, S24, S36, S46 ) & 7 \\
\hline & & $\begin{array}{l}\text { İşbölümü yaparak çözeriz : ( S13, S17, S18, S20, S21, S30, } \\
\text { S31, S33, S34,S38, S39, S49 ) }\end{array}$ & 12 \\
\hline & & Herkesin fikrini dikkate alarak çözeriz : ( S26, S47, S50 ) & 3 \\
\hline \multirow[t]{2}{*}{ Diğer } & Birey Etkisi & $\begin{array}{l}\text { Önce tek tek çözer, sonra çözümlerimizi karşılaştırırız : } \\
(\text { S15, S43 ) }\end{array}$ & 2 \\
\hline & Nötr & Katılmam: ( S40 ) & 1 \\
\hline
\end{tabular}

Tablo 4 incelendiğinde öğrencilerin işbirlikli problem çözme sürecine yönelik görüşlerinin grup etkisi ve diğer olarak iki kategoride toplandığ1 görülmektedir. En çok ortak fikir bulma (14) ve en az ise katılmam (1) görüşünün ifade edildiği görülmektedir. Bazı öğrencilerin ise işbölümü yaparak çözme (12), tartışma (7) ve birleştirme (6), sırayla söyleme (5) görüşlerini ifade ettikleri görülmektedir. Öğrencilerin arkadaşları ile birlikte bir grup olarak ortak fikir bulmaya çalıştıkları ve işbirliği yaptıkları görüşlerini ifade ettikleri görülmektedir. Bu bulguya yönelik öğrencilerin görüşlerinden örnekler aşağıda sunulmuştur.

S4: " Ilk herkesin fikri alınır ve sonra da ortak bir karara varılır "(Bütünlük teması örnek görüş).

S7: “ Hepimizin fikrini değerlendirir, ortak bir karar bulmaya çalışırız " (Bütülük teması örnek görüş).

S8: " Herkes strayla fikrini söyler biz de düşünerek en mantıkl sonuca ulaşmak için yapmamız gerekenleri yaparız, işbölümü ile yaparız "(Bütünlük tmeası örnek görüş). 
S40: “ Bunun doğru olmadiğım bilsem de kendi kafamın estiğine göre yaparım, diğerlerinin doğru düşünmediğini bildiğim için onların fikirlerini önemsemem " (Nötr temas1 örnek görüş).

S41: "Ben ve arkadaşlarım hepimizin en iyi yönünü kullanarak çözeriz" (Eşitlik teması örnek görüş).

S47: "Bilmediğim veya anlamadığım soruları arkadaşlarıma danışırım veya bir problem üzerinde başka bir çözüm yolu deneriz" (Eşitlik teması örnek görüş).

İşbirlikli problem çözme sürecine yönelik öğrencilerin tutumları nasıldır?

Öğrencilerin işbirlikli problem çözme sürecine yönelik tutumları Tablo 5’de verilmiştir.

Tablo 5.1

Öğrencilerin İşbirlikli Problem Çözme Sürecine Yönelik Tutumları

\begin{tabular}{|c|c|c|}
\hline $\begin{array}{l}\text { Bir proble } \\
\text { Tema }\end{array}$ & $\begin{array}{l}\text { cözerken arkadaşlarınla birlikte çalışırsan ne hissedersin? } \\
\text { Kod }\end{array}$ & f \\
\hline \multirow{6}{*}{$\begin{array}{l}\text { Olumlu } \\
\text { Etki }\end{array}$} & $\begin{array}{l}\text { Mutlu oluyorum: ( S1, S2, S3, S4, S5, S7, S9, S10, S14, S16, S17, S19, S20, } \\
\text { S24, S26, S27, S28, S30, S33, S36, S29, S39, S42, S43, S44, S45, S48 ) }\end{array}$ & 27 \\
\hline & Birlikte paylaşım duygusu hissediyorum : ( S11, S23, S25, S31) & 4 \\
\hline & İyi hissediyorum : ( S32, S34, S35 ) & 3 \\
\hline & Zeki hissediyorum : ( S6, S13 ) & 2 \\
\hline & Heyecanlı hissediyorum : ( S28, S41, S49) & 2 \\
\hline & Kendime güvenim artıyor : ( S15, S18, S37 ) & 2 \\
\hline $\begin{array}{l}\text { Olumsuz } \\
\text { Etki }\end{array}$ & $\begin{array}{l}\text { Birlikte problem çözmekten hoşlanmıyorum : ( S21, S14, S22, S28, S40, } \\
\text { S46, S47) }\end{array}$ & 7 \\
\hline Nötr & Ne iyi ne de kötü bir duygu: S (47), S (50) & 2 \\
\hline
\end{tabular}

Tablo 5 incelendiğinde öğrencilerin işbirlikli problem çözmeye yönelik tutumlarının olumlu etki, olumsuz etki ve nötr olarak üç temada toplandığı, en çok olumlu etki temasinda mutlu olma (27) ifadesi ve daha sonra ikinci sirada olumsuz etki temasında hoşlanmıyorum (7) ifadesinin kullanıldığı, iki öğrencinin ise (2) herhangi bir duygu hissetmediğini belirttiği görülmektedir. Bazı öğrencilerin paylaşım (4), iyi hissetme (3), heyecan (2) ve güven (2) görüşlerini ifade ettikleri görülmektedir. Öğrencilerin arkadaşları ile birlikte problem çözmekten çoğunlukla mutlu olduklarını ifade ettikleri görülmektedir. Yedi öğrenci ise işbirlikli problem çözmekten hoşlanmadıklarını belirtmektedir. Bu bulguya yönelik öğrencilerin görüşlerinden örnekler aşağıda sunulmuştur.

S47 : "Kötü bir duygu değil aslında iyi bir duygu da değil, tam olarak orta düzeyde şeyler bence" (Nötr teması örnek görüş).

S41: “ Bence güzel hem eğlenceli oluyor hem de yeni şeyler öğrenebiliyorum " (Olumlu etki teması örnek görüş).

S10: “ Böyle bir durumda ben bana yardım eden bir arkadaşım olduğu için çok mutlu olurum" (Olumlu etki teması örnek görüş).

S18 : "Sorunu daha çabuk çözebileceğimizi düşündüğ̈̈m için mutlu olurum "( Olumlu etki teması örnek görüş).

S50: "Bu durum benim için bir şey ifade etmiyor" (Nötr teması örnek görüş).

Öğrencilerin işbirlikli problem çözme sürecinde arkadaşının görüşü ile ilgili düşünceleri nelerdir? 
Öğrencilerin işbirlikli problem çözme sürecinde arkadaşının görüşü ile ilgili düşünceleri Tablo 6’da verilmiştir.

Tablo 6.2

Öğrencilerin İşbirlikli Problem Çözme Sürecinde Arkadaşının Görüşü İle İlgili Düşünceleri

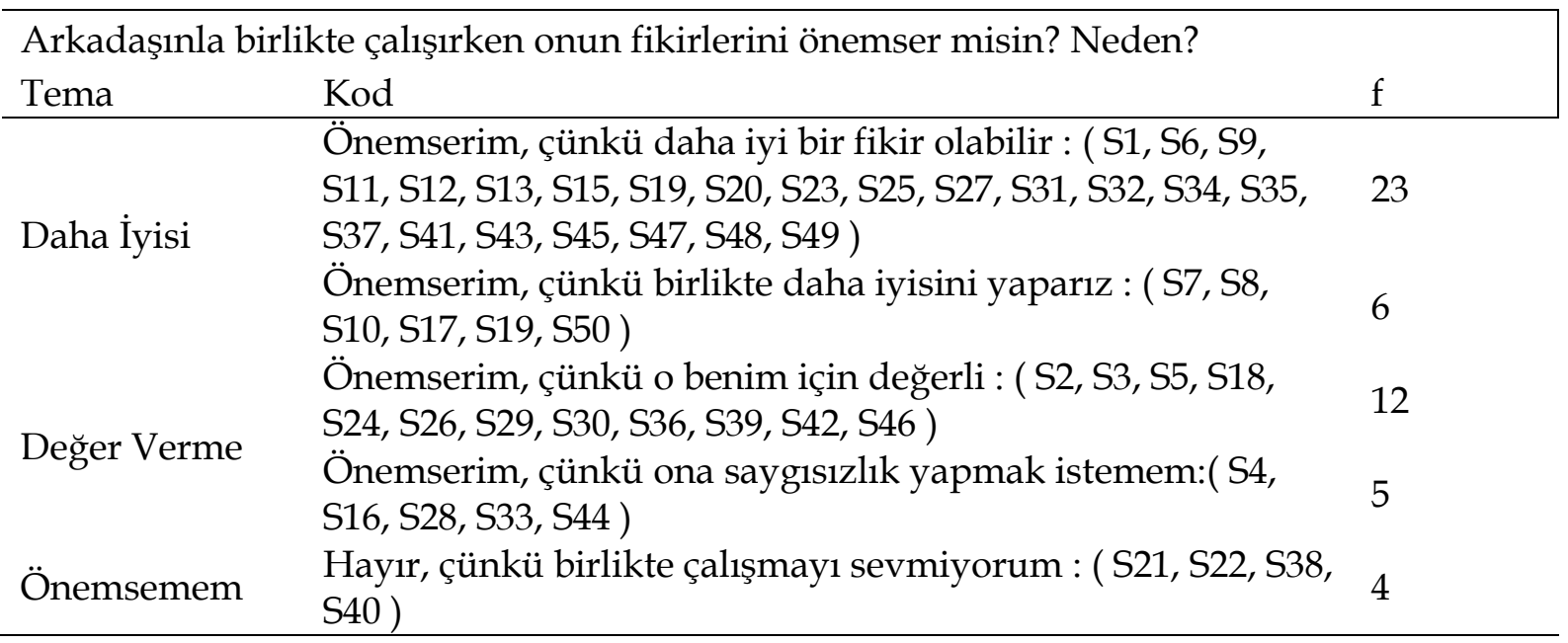

Tablo 6 incelendiğinde görüşlerin daha iyisi, değer verme ve önemsememe temalarında toplandığı görülmektedir. Öğrencilerin çoğunlukla arkadaşının fikrini daha iyi bir fikir öne sürebileceği için (23) önemsediği, bir kısmının ise (12) arkadaşına değer verdiği için, daha iyisini yapabilecekleri için(6) önemsediğini, az bir kısmının ise (4) arkadaşının fikrini önemsemediğini ifade ettikleri görülmektedir. Öğrencilerin arkadaşının fikrini önemsemesi ile ilgili örnek görüşleri şu şekildedir;

S(50): "Arkadaşımın fikrini önemserim çünkü bilmediğimizi birbirimize sorarız"(Daha iyisi teması örnek görüş).

S(15) : "Evet önemserim çünkü belki benim bildiğim yanlıştır, onun bildiği doğrudur” (Daha iyisi teması örnek görüş).

S(19) : "Arkadaşımın tepkisini önemserim çünkü herkese saygı duymalıyız "(Daha iyisi teması örnek görüş).

S(22): “ Hayır, arkadaşımın ne düşündüğünü önemsemem "(Önemsemem teması örnek görüş).

Öğrencilerin grup içinde baskın olan arkadaşlarının davranışlarına ilişkin görüşleri nelerdir?

Öğrencilerin grup içinde baskın olan arkadaşlarının davranışlarına ilişkin görüşleri Tablo 7' de verilmiştir.

Tablo 7 incelendiğinde görüşlerin tepki, tutum ve kabul temalarında toplandı̆̆ öğrencilerin büyük bir bölümünün (42) arkadaşının grup içinde baskın olması durumunda ona tepki vereceğini ifade ettiği görülmektedir. Bazı öğrenciler uyarama (25), bazı öğrenciler ise arkadaşlığını bitirme (5) ve sinirlenme (8) görüşlerini ifade etmektedirler. Bir kısım öğrenci ise bu durumda olumsuz bir tutuma sahip olacağını (2), diğer öğrencilerin ise durumu olduğu gibi kabul edeceklerini belirttikleri görülmektedir (5). Bu bulguya yönelik öğrencilerin görüşlerinden örnekler aşağıda sunulmuştur. 
Tablo 7.3

Öğrencilerin Grup İçinde Baskın Olan Arkadaşlarının Davranışlarına İlişkin Görüşleri

Arkadaşlarından biri her zaman kendi söylediğinin yapılmasını isterse ne yaparsın?

\begin{tabular}{lll} 
Tema & Kod & $\mathrm{f}$ \\
\hline & Onu uyarırım, herkesi dinlemesini isterim : ( S1, S2, S4, S7, S8, & \\
\multirow{3}{*}{ Tepki } & S9, S14, S15, S19, S23, S26, S27, S30, S31, S33, S34, S38, S40, S41, & 25 \\
& S42, S43, S44, S45, S47, S49) & \\
& Arkadaşlı̆̆ımı bitiririm : ( S5, S17, S21, S22, S37 ) & 5 \\
& Sinirlenirim : ( S3, S11, S13, S16, S18, S24, S28, S39) & 8 \\
& Onun söylediğgini yapmam : ( S12, S25, S46, S50) & 4 \\
Tutum & Üzülürüm : ( S32 ) & 1 \\
Kabul & Onunla bir daha çalışmak istemem : ( S29) & 1 \\
\hline
\end{tabular}

S(29): “ Onunla bir daha çalışmak istemem "(Tutum teması örnek görüş).

S(8): " Ondan bizim fikirlerimizi de dinlemesini isterim, bunun bir takım çalışması olduğunu söylerim "(Tepki teması örnek görüş).

S(41): "Bunun yanlış olduğunu, bunu yapmaması gerektiğini söylerim, belki de diğger insanlar ondan daha fazla deneyimlidir" (Tepki teması örnek görüş).

S(47): "Ona neden böyle yaptığın sorarm ve cevabı dinledikten sonra da ona fikirlerimi sunar, herkesi dinlemesi gerektiğini söylerim "(Tepki teması örnek görüş).

Öğrencilerin işbirlikli problem çözme sürecinde karşılaşabilecekleri fikir uyuşmazlığını çözmeye yönelik görüşleri nelerdir?

Öğrencilerin işbirlikli problem çözme sürecinde karşılaşabilecekleri fikir uyuşmazlığını çözmeye yönelik görüşleri Tablo 8'de verilmiştir.

Tablo 8 incelendiğinde ortak noktaya ulaşmaya dair görüşlerin ölçüt belirleme ve diğer kategorilerinde toplandığı, öğrencilerin grup içinde ortak bir noktaya ulaşmak için çoğunlukla demokratik bir yaklaşım (37) sergiledikleri, en az ise tesadüfi temasında kura çekme (1) ve kolaylık temasında ise öğretmene sorma (1) görüşlerini ifade ettikleri görülmektedir. İşbirlikli problem çözme sürecinde anlaşmazlık durumunda ise görüşlerin uyum, çözüm ve diğer kategorilerinde toplandığı, en çok konuşma (11), ortak noktayı bulma (7) ve oylama ve herkesi dinleme (6) olarak en az ise grup başkanının kararını dinleyerek (1) anlaşmazlığı çözebilecekleri düşüncelerini ifade ettikleri görülmektedir. Öğrencilerin işbirlikli problem çözme sürecinde ortak noktaya ulaşmaya ve grup içinde anlaşmazlığı çözmeye yönelik örnek görüşleri şu şekildedir;

S(4): "Hepimizin kabul edeceği bir karar veririz ya da oylama yaparı" (Demokratik yaklaşım teması örnek görüş).

S(7) : "Hangisinin doğru olduğunu araştırır, ondan sonra karar veririz" (Doğru cevap teması örnek görüş).

S(25) :"Herkesin hoşgörülü olması ve duygudaşlık kurmasıyla çözülür "(Anlayış teması örnek görüş).

S(13) : "Doğru cevabı öğretmene sorarak çözeriz" (Vazgeçme teması örnek görüş).

$S(42)$ : "Oy birliği ile çözülür" (Anlaşma teması örnek görüş). 
Tablo 8.4

Öğrencilerin İşbirlikli Problem Çözme Sürecinde Karşılaşabilecekleri Fikir Uyuşmazlığını Çözmeye Yönelik Görüşleri

\begin{tabular}{|c|c|c|c|}
\hline \multicolumn{4}{|c|}{$\begin{array}{l}\text { Bir grup olarak problem çözerken, arkadaşların farklı şeyler söylerse ya da yapmak isterse ortak bir } \\
\text { noktaya ulaşmak için neler yapılır? }\end{array}$} \\
\hline Kategori & Tema & Kod & $\mathrm{f}$ \\
\hline \multirow{10}{*}{$\begin{array}{l}\text { Ölçüt } \\
\text { Belirleme }\end{array}$} & \multirow{5}{*}{$\begin{array}{l}\text { Demokratik } \\
\text { Yaklaşım }\end{array}$} & $\begin{array}{l}\text { Herkesin fikri alınır, en iyisi seçilir : ( S1, S3, S8, S14, } \\
\text { S20, S21, S24, S26, S28, S34, S38, S41, S43, S44, S45, } \\
\text { S47, S50 ) }\end{array}$ & 17 \\
\hline & & Konuşup oybirliğiyle belirlenir: ( S2, S4, S5, S9, S10, & \\
\hline & & S11, S17, S18, S29, S30, S31, S35, S37, S39, S42, S46, S49 & 17 \\
\hline & & & \\
\hline & & $\begin{array}{l}\text { Tartışarak seçeriz : (S13, S15) } \\
\text { İsbirliği ile : (S33) }\end{array}$ & $\begin{array}{l}2 \\
1\end{array}$ \\
\hline & \multirow{3}{*}{ Doğru Cevap } & Kim fikrinin doğru olduğunu ispat ederse onunkini & \\
\hline & & seçerim : ( S12, S19, S23, S32 ) & 4 \\
\hline & & En doğrusunu seçerim :( S7 ) & 1 \\
\hline & \multirow{2}{*}{ Kolaylık } & Arkadaşlarımın dediğini yaparım:(S6, S16, S27, S40 ) & 4 \\
\hline & & Öğretmene sorarız : ( S48 ) & 1 \\
\hline \multirow[b]{2}{*}{ Diğer } & Tesadüfi & Kura çekeriz :( S22 ) & 1 \\
\hline & Anlayış & Hoşgörü ile seçilir : ( S25 ) & 1 \\
\hline Kategori & Tema & Kod & $\mathrm{f}$ \\
\hline \multirow{6}{*}{ Uyum } & \multirow{2}{*}{ İletişim } & $\begin{array}{l}\text { Herkesi teker teker dinleyerek : ( S3, S24, S30, S41, } \\
\text { S43, S45 ) }\end{array}$ & 6 \\
\hline & & $\begin{array}{l}\text { Konuşarak : ( S1, S4, S5, S12, S19, S20, S23, S29, S36, } \\
\text { S38, S46 ) }\end{array}$ & 11 \\
\hline & \multirow{4}{*}{ Anlaşma } & $\begin{array}{l}\text { Ortak noktay1 bularak : ( S10, S14, S17, S26, S27, S34, } \\
\text { S44 ) }\end{array}$ & 7 \\
\hline & & Oylama yaparak : ( S2, S21, S31, S42, S49, S50 ) & 6 \\
\hline & & Empati kurarak : ( S7, S25, S28 ) & 3 \\
\hline & & Uyararak : (S18, S33 ) & 2 \\
\hline \multirow{3}{*}{ Çözüm } & Onay & Grup başkanının kararını dinleyerek : ( S15 ) & 1 \\
\hline & \multirow{2}{*}{ Belirleme } & Sorun çıkaranı gruptan çıkararak : ( S16, S37 ) & 2 \\
\hline & & Anlaşmazlığın nedenini bulurum:(S8, S11, S47, S48 ) & 4 \\
\hline \multirow{3}{*}{ Diğer } & \multirow{2}{*}{ Vazgeçme } & Olduğu gibi birakarak : ( S22, S35, S40 ) & 3 \\
\hline & & Öğretmene sorarak : ( S13, S32, S39 ) & 3 \\
\hline & Tekrar Deneme & Ara vererek: ( S6, S9) & 2 \\
\hline
\end{tabular}

\section{Tartışma, Sonuç ve Öneriler}

İhtiyaç analizi doğrultusunda yarı yapılandırılmış öğrenci görüşme formundan elde edilen sonuçlar öğrencilerin problem kavramına yönelik görüşlerinin sonuç odakl, sosyal bağlam, ders içeriği ve olumsuzluk şeklinde dört temada toplandığını göstermektedir. Öğrenci görüşleri problemi en fazla, çözülmesi gereken bir matematiksel bir sorun olarak algıladıklarını göstermektedir. Nitekim problem denince ilk olarak akla ilkokul sayısal ders kitaplarından elde edilen bir anlayışla konu sonlarında verilen dört işleme dayalı matematik problemleri gelmektedir (Heddens ve Speer, 1997, Akt. Altun, 2000). Literatürde sıklıkla matematik ve fen eğitimi alanlarında problem çözme üzerine birçok çalışma yapılmasına karşın problem çözme sosyal bilgiler eğitiminde en az çalışılan konulardan biridir (Bilge, Türk, Bilge ve Deniz, 2015). Öğrencilerin zihinlerinde problem şemalarının sayısal derslerle sınırlı 
olmasının, sosyal problemleri birer problem olarak düşünmelerine engel oluşturduğu söylenebilir. Yapılan birçok çalışmada (Karakuş, 2017; Ulusoy ve Çakıroğlu, 2017; Okazaki ve Fujita, 2007) prototip örneklerin öğrencilerin kavramlara yönelik sınırlı anlamalar hatta yanlış anlamalar oluşturmalarına neden olduğu ifade edilmektedir. Bunun yanında okul ortamlarında çoğunlukla sayısal problem çözme uygulamalarının yapılması bu durumun bir diğer nedeni olarak görülebilir. Oysaki öğrencinin zihninde bu şemanın genişlemesi ve öğrencilerin sosyal problem çözme becerisine de sahip olması gerekmektedir. Ayrıca sosyal problemler öğrencilerin günlük hayatta daha fazla karşılaştıkları problemler olarak görülmektedir. $\mathrm{Bu}$ bağlamda literatürde sosyal problem çözme becerisi arttıkça öğrencinin sosyal yetkinliğinin arttığı, kızgınlık-saldırganlık davranışlarının (Yaralı ve Özkan, 2016) davranış bozukluklarının azaldığı (Dereli , 2013) ve toplum içine daha çok kabul edildikleri (Parker ve Asher, 1993) belirtilmektedir. Yaralı ve Özkan (2016) çalışmalarında sosyal problem çözme becerisi artan öğrencilerin kızgınlık ve saldırganlık davranışlarının azaldığını belirtirken Ireland (2001) ise sosyal problem çözme becerisi gelişmeyen bireylerin ilerleyen yıllarda saldırganlık gibi istenmeyen davranışları gösterme ihtimallerinin yüksek olduğunu ifade etmektedir.

İhtiyaç analizi doğrultusunda yarı yapılandırılmış öğrenci görüşme formundan elde edilen bir başka sonuç ise öğrencilerin problem çözme eylemine yönelik görüşlerinin ise başarı elde etme, çaba gösterme, refaha kavuşma ve nötr olarak dört temada toplandığı belirlenmiştir. Öğrencilerin problem çözme eylemi için en çok doğru cevabı bulmak, sorun çözmek ve uğraşmak şeklinde görüş bildirdikleri görülmektedir. Bu durum öğrencilerin problem çözme eylemine yönelik daha çok sonuç odaklı bir düşünceye sahip olduklarını göstermektedir. Literatürde de benzer şekilde problem çözme insanların karşılaştıkları problemlere etkin çözüm bulabilmek amacıyla oluşturdukları süreçler (D'Zurilla, Nezu ve Nezu, 2007), bir sonuç, bir yol bulma (Polya, 1990) ya da bireyin karşısına çıkan sorunları çözme süreci (Bingham, 1988) olarak tanımlanmaktadır. Problem çözme statik değil dinamik bir süreçtir (Baki, 2008). Bu açıdan bakıldığında problem çözme bir eylemi ifade etmektedir. Öğrencilerin bu konudaki anlayışları ise eylemden ziyade daha çok sonucu işaret etmektedir. Problem çözme bireyin yaşamında önemli bir yere sahiptir. Çünkü problem çözme becerisine sahip olan bireyler karşılaştıkları sorunların üstesinden daha rahat gelebilmektedirler (Beck, 2001). Problem çözme becerisi öğrencilerin sorumluluk sahibi olmasını ve araştırmaya ve öğrenmeye yönelik motivasyonunun artmasını sağlamaktadır (Fisher, 1990). Problem çözme becerisi öğrencinin bilgiyi kullanmasını, yaratıcılığını geliştirmesini ve kavramları daha iyi anlamasını sağlar.

Öğrencilerin arkadaşlarıyla birlikte problem çözmeye yönelik görüşleri birlikte problem çözmelerinin daha eğlenceli olduğu ve arkadaşları ile birlikte daha hızlı problem çözdükleri yönündedir. Bu bağlamda öğrencilerin işbirlikli olarak problem çözmekten mutlu oldukları ve verilen görevi daha kolay yerine getirdikleri söylenebilir. Literatürde işbirlikli problem çözmenin, bireysel problem çözme etkinliklerine göre daha üretici olduğu ve sorun çözümünde daha uygun olduğu ifade edilmektedir. Bunun nedeni işbirlikli problem çözme sürecinde, tüm grup üyelerini memnun edecek bir sonuca ulaşılması hedeflenmektedir (Wooldridge ve Jennings, 1999). İşbirlikli problem çözmenin bireysel problem çözmeden farkı, bireysel problem çözme sürecinde öğrenci kendi bakış açısına göre uygun olduğunu düşündüğü bir 
yolda ilerlemektedir. Buna karşın işbirlikli problem çözmede ise öğrenci diğer arkadaşlarının farklı görüşlerini de görür ve onlara hangi açılardan katıldığının ya da katılmadığının farkına varır (Tam, 2013; Fiore et.al.,2017). Bunun yanında bireysel olarak problem çözmede öğrenci çözüm için ya sınırlı sayıda çözüm önerecek ya da bir çözüm yolu bulamayacaktır. Oysa işbirlikli ortamlarda bir problemin çözümü için birden fazla alternatif yolun ortaya çıkma potansiyeli daha yüksektir. Ayrıca işbirlikli problem çözme ile verilen problem durumu bireysel çaba harcandiğında geçen süreden daha hızlı bir şekilde çözülmektedir. Bu hızlı işbirliği grup üyelerinin kendilerini bireysel olarak da geliştirmelerine katkı sağlamaktadır (Clearwater, Huberman ve Hagg, 1991).

Öğrencilerin işbirlikli problem çözme sürecinde ne yapıldığına dair görüşleri incelendiğinde öğrencilerin bu tür ortamlarda arkadaşları ile birlikte bir grup olarak ortak fikir bulmaya çalıştıkları, tartıştıkları ve işbirliği yaptıkları şeklinde düşüncelere sahip oldukları belirlenmiştir. Literatürde Rajas, Drummand ve Mercer (2003) işbirlikli problem çözme ile öğrencinin sınıf ortamında arkadaşları ile görüşlerini paylaşmasının, farklı bakış açılarını görmesinin, ortak bir sonuca varmadan önce muhtemel alternatifleri tartışıp bunları değerlendirmesinin önemli olduğunu ifade etmektedir. Chiu (2000) ise işbirlikli problem çözmede farklı bakış açlarının, grupta çok sayıda fikrin ortaya çıkmasını sağladığını ve bu fikirlerin bir araya getirilmesinin ve yorumlanmasının öğrenciyi olumlu etkilediğini belirtmektedir. Rosen (2015) işbirlikli problem çözme sürecinde öğrencinin bir fikir sunmasının, bu öneriyi grup arkadaşlarıyla paylaşmasının gerekli olduğunu belirtmektedir. İşbirlikli problem çözme sürecinde öğrenciler birbirlerinin öğrenimini destekler, farklı bakış açılarını görür, arkadaşları tarafından önerilen alternatifleri değerlendirir, grup arkadaşlarına sayg1 duyar, nezaket gösterir (Mulrey, 2017). Griffin, Care ve McGaw (2012) benzer şekilde işbirlikli problem çözmenin başkalarının bakış açılarını fark etme becerisi ile doğrudan bağlantılı olduğunu, bilgiyi, deneyimi, tecrübeyi katk1 sağlayarak yapılandırma amacı olduğunu, eksiklerin neler olduğunu ve bu eksiklerin nasıl tamamlanacağının belirlenmesi gerektiğini, bir problemin çözümünde durumun ve çözümün farkına varmanın önemini belirtmektedir.

Öğrencilerin işbirlikli problem çözme sürecine yönelik tutumları incelendiğinde öğrencilerin arkadaşlarıyla birlikte çalışarak problem çözmeye olumlu yaklaştıkları sonucu elde edilmiştir. Elde edilen bulgular öğrencilerin arkadaşları ile birlikte problem çözmekten çoğunlukla mutlu olduklarını göstermektedir. Tam (2013) işbirlikli problem çözmenin öğrenciler üzerinde olumlu bir etkisi olduğunu, Nebesniak (2007) ise işbirlikli problem çözmenin öğrencilerin özgüvenini arttırdı̆̆ını, Poore (2008) ise işbirlikli problem çözmenin öğrencilerin derslere karşı daha olumlu bir bakış açısına sahip olmalarını sağladığı belirtmektedir. Bu bağlamda işbirlikli problem çözmenin öğrenci için olumlu etkileri olduğu görülmektedir.

Öğrencilerin arkadaşlarının görüşlerini almalarının en önemli nedeni daha iyi fikirlerin ortaya çıkabileceği düşüncesidir. Bunun yanında bazı öğrenciler arkadaşlarıyla olan arkadaşlık bağları nedeniyle duygusal olarak arkadaşlarının düşüncesini almanın önemli olduğunu ifade etmektedirler. Buna karşın öğrencilerin çok az kısmı ise arkadaşının fikrini önemsemediğini belirtmektedir. Yapılan çalışmalarda işbirlikli problem çözme sürecinde grup üyelerinin birbirlerini hem bilişsel hem de duyuşsal olarak etkileyebilecekleri ifade edilmektedir (Chiu, 2000). 
İşbirlikli öğrenmenin dayandığı sosyal bağlılık teorisine göre ortak hedefe ulaşmak için gösterilen çaba bireyler arası pozitif bağların kurulmasını desteklemektedir. Bu bağlar, grubun dinamik bir yapıya sahip olmasına katkı sağlamaktadır. Bu bağlamda öğrencinin farklı fikirde olsa da arkadaşının fikrini dinlemesi önemlidir. Bunun nedeni etkili bir grup çalışmasında, öğrencilerin fikirlerini paylaşmasının, risk almasının, grup arkadaşları ile aynı fikirde olmamasının ve bu noktada grup arkadaşlarını dinlemesinin, kendi bakış açısını oluşturmasının ve grup arkadaşları ile uzlaşmasının önemini anlaması gerekmektedir (Blumenfeld, Marx, Soloway ve Krajcik, 1996).

Grup içinde baskın olan arkadaşlarının işbirlikli problem çözme süreci üzerindeki etkisine yönelik öğrencilerin büyük bir bölümü arkadaşının grup içinde baskın olmasını istemediğini ve böyle bir duruma izin vermeyeceğini ifade etmektedir. Buna karşın çok az öğrencinin ise bu gibi bir durumu olduğu gibi kabul edeceklerini belirttikleri tespit edilmiştir. Karşılıklı bir iletişim içeren işbirlikli problem çözmede öğrencilerin birbirlerini dinlerken dikkat etmeleri gereken bazı noktalar vardır. Bunlar; arkadaşına yeterli zaman vererek onu saygı ile dinlemek, ona karşı çıkmamak, ona müdahale etmemek, onu anlamaya çalışmaktır (UNESCO/APC, 2013). Literatürde yapılan çalışmalar incelendiğinde grup içinde bazı öğrencilerin diğer öğrencilere baskı kurdukları ifade edilmektedir (Yasul ve Samancı, 2015; Aksu, 1996). Grup çalışması esnasında grup içinde baskı kurulması da bir çeşit zorbalık olarak değerlendirilebilir (Akyol, Yıldız ve Akman, 2017). İşbirlikli problem çözme gruplarında bir üyenin hâkimiyeti ve diğerlerinin çalışmalara katılmaması söz konusu olamaz. Bu bağlamda bu tür bir sorunun oluşmaması ve sürece tüm üyelerin katılabilmesi için işbirlikli problem çözmede gruplarının rastgele olarak oluşturulması gerekmektedir (Way, 2011).

Fikir uyuşmazlıklarını çözmeye yönelik öğrencilerin görüşleri incelendiğinde öğrencilerin grup içinde ortak bir noktaya ulaşmak için çoğunlukla demokratik bir yaklaşım sergiledikleri, en az ise kura çekme ve öğretmene sorma görüşlerini ifade ettikleri belirlenmiştir. İşbirlikli problem çözme sürecinde anlaşmazlık durumunda ise en çok iletişim ve çözüm odaklı olarak, en az ise ara vererek anlaşmazlığ çözebilecekleri düşüncelerini ifade ettikleri sonucuna ulaşılmıştır. İşbirlikli problem çözme ile öğrenci hem sosyal iletişim becerisini hem de problem çözme becerisini geliştirecektir. Farklı bakış açılarını, farklı çözüm yollarını görmek öğrencinin de ufkunun genişlemesine daha detaylı ve çok boyutlu düşünmesine yardımcı olacaktır. Bununla birlikte, birbirlerine çözüme dair fikirlerini anlatmaları öğrencilerin kendi bakış açılarını irdelemelerini ve varsa eksikliklerini görmelerini sağlayacaktır. Yurt dışında yapılan bazı araştırmalarda da grup çalışmalarında benzer sorunların yaşandığı görülmektedir. Daly ve Worrell (1993), tarafından yapılan araştırmalarda öğrencilerin grup arkadaşları ile sorun yaşadı $\breve{1}$ tespit edilmiştir. Grup içi iletişim sorunları, bir araya gelindiğinde anlaşamama ve zamanın boşa geçmesi grup çalışmalarını olumsuz yönde etkilemektedir. Hatta derse güdülenmiş ve grup çalışması yapmak isteyen öğrenciler, gruptaki diğer üyeler çalışmadığında hayal kırıklığına uğramakta ve kendisini çalışmadan çekmektedir (Pauli, Mohiyeddini, Bray, Michie ve Street, 2008). Grup içinde anlaşmazlık yaşanması, her ne kadar bazen olumsuz bir durum olarak görülse de (Yeşilyurt, 2010; Bilen, 1999) , oluşan tartışma ortamı görüş alış verişini yapılmasını sağlar (Çakmak, 2014). İşbirlikli problem çözme sürecinde grup üyeleri birlikte tartışarak problem durumunun daha iyi anlar, olası 
çözüm yollarının neler olabileceğini görür ve sonuçta hangi çözüm yolunu kullanılacağına karar verebilir. Bu noktada öğrenciler ortak hedef için aldıkları kararların sonuçlarını birlikte taşır ve grup olarak bu sorumluluğu paylaşırlar. İşbirlikli çalışma öğrencinin arkadaşına olan güvenini ve iç motivasyonunu artırır. Böylece öğrencinin sosyal iletişim becerisi, anlaşmazlık çözme becerisi gelişir, öğrenciler grup içinde farklı düşünen bireyleri nasıl kabul edeceğini, onları nasıl destekleyeceğini öğrenir (Johnson ve Johnson, 1989).

Öğrencilerin ihtiyaç analizi sürecinde problemi sorun, problem çözmeyi ise sorun çözmek olarak tanımladıkları, problemi tek başına çözmek yerine arkadaş grubunda çözmenin daha kolay ve daha eğlenceli olduğunu düşündükleri, bu süreçte ortak fikir bulmak için çaba sarf ettiklerini ifade ettikleri belirlenmiştir. Öğrencilerin bununla birlikte arkadaş grubu ile problem çözerken mutlu oldukları, arkadaşlarını ve onların fikirlerini önemsediklerini ifade ettikleri belirlenmiştir. Anlaşmazlık durumunda ise öğrencilerin herkesin fikrinin alınması gerektiğini, grupta baskın bir arkadaşları varsa onun uyarılmasının etkili olacağını düşündükleri tespit edilmiştir.

\section{Öneriler}

Bu çalışmadan elde edilen sonuçlar kapsamında şu önerilerde bulunulmaktadır;

1. Öğrencilerin sosyal problem algılarının geliştirilmesi, problem kavramına yönelik algılarının genişletilmesine katkı sağlayacaktır.

2. Öğrencilerin birlikte problem çözmekten mutlu oldukları, arkadaşlarının düşüncelerine ve ortak bir grup anlayışına önem verdikleri dikkate alındığında hazırlanacak olan bir işbirlikli problem çözme öğretim programı öğrencilerin işbirlikli problem çözme becerilerinin geliştirilmesine katkı sağlayacaktır.

\section{Kaynakça}

Adıgüzel, O. C. (2016). Eğitim Programlarının Geliştirilmesinde İhtiyaç Analizi El Kitabı. Ankara: Anı Yayıncılık.

Aksu, M. B. (1996). İnsan ilişkilerinde bir boyut: grup davranışı. Kuram ve Uygulamada Eğitim Yönetimi, 7(7), 311-328.

Akyol, N. A., Yıldız, C. ve Akman, B. (2017). Öğretmenlerin akran zorbalığına ilişkin görüşleri ve zorbalıkla baş etme stratejileri. Hacettepe Üniversitesi Ĕ̆itim Fakültesi Dergisi, 33(2), 439-459.

Altun, M. (2000). İlköğretimde problem çözme öğretimi. Milli Ĕ̆itim Dergisi, 147, 2733.

Arsal, Z. (1998). Program geliştirme sürecinde ihtiyaç analizinin yeri ve nasıl yapıldı̆̆ına ilişkin program geliştirme uzmanlarının görüşleri. (Yayınlanmamış yüksek lisans tezi). Abant İzzet Baysal Üniversitesi, Sosyal Bilimler Enstitüsü, Bolu.

Atwood, H. M. ve Ellis, J. (1971). The concept of need: an analysis for adult education. Adult Leadership, 19, 210-212; 244.

Azimi, H. M. ve Rahmani, R. (2013). Importance of needs assessment for implementation of e-learning in colleges of education. International Journal of Information and Computation Technology, 377-382.

Baki, A. (2008). Kuramdan Uygulamaya Matematik Ĕ̆itimi. Ankara: Harf Eğitimi Yayıncılı̆̆ı.

Barth, J. L. - Demirtaş, A. (1997). İlköğretim Sosyal Bilgiler Öğretimi. Ankara: YÖK/Dünya Bankası Milli Eğitimi Geliştirme Projesi. 
Beck, J.S. (2001). Bilişsel Terapi Temel İlkeler ve Ötesi. Ankara: Türk Psikologlar Derneği Yayınları.

Bernard, H. R. (2002). Research Methods in Anthropology: Qualitative and quantitative methods. UK: Altamira Press.

Bilen, M. (1999). Plandan Uygulamaya Öğretim. Ankara: Anı Yayıncılık.

Bingham, A. (1988). Çocuklarda Problem Çözme Yeteneklerinin Geliştirilmesi. Ankara: Millî Eğitim Basımevi.

Blumenfeld, P. C., Marx, R. W., Soloway, E. ve Krajcik, J. (1996). Learning with peers: from small group cooperation to collaborative communities. Educational Researcher, 25(8), 37-39. https:/ / doi.org/10.3102/0013189X025008037

Bosher, S. ve Smalkoski, K. (2002). From needs analysis to curriculum development: designing a course in health-care communication for 1mmigrant students in the USA. English for specific purposes, 21(1), 59-79. https:/ / doi.org/10.1016/S0889-4906(01)00002-3

Chiu, M. M. (2000). Group Problem solving processes: social interactions and individual actions. Journal for the Theory of Social Behaviour, 30(1), 27-49. https:/ / doi.org/10.1111/1468-5914.00118

Clearwater, S. H., Huberman, B. A. ve Hogg, T. (1991). Cooperative solution of constraint satisfaction problems. Science, 254(5035), 1181. https:/ / doi.org/10.1126/ science.254.5035.1181

Corbetta, P. (2003). Social Research Theory, Methods and Techniques. London: SAGE Publications. https:/ / doi.org/10.4135/9781849209922

Çakmak, M. (2014). Grup çalışmasına yönelik yansımalar: öğretmen adaylarının düşünceleri. Eğitim ve Bilim, 39(174), 338-347. https:/ / doi.org/10.15390/EB.2014.2275

Çepni, S. (2016). PISA ve TIMMS Mantı̆̆ıı ve Sorularını Anlama. Ankara: Pegem Akademi. https:// doi.org/10.14527/9786053186359

Daly, J.P. ve Worrel, D.L. (1993). Structuring group projects as miniature organizations. Management Education, 17, 236-242. https:/ / doi.org/10.1177/105256299301700208

Dereli, E. (2013). Çocuklar için sosyal problem çözme ölçeğinin 6 yaş grubu için türkiye uyarlaması ve okul öncesi davranış problemleri ile sosyal problem çözme becerileri arasındaki ilişkiler. Kuram ve Uygulamada Ĕ̆itim Bilimleri,13 (1), 479-498.

D'Zurilla, T. J., Nezu, A. M. ve Nezu, C. M. (2007). Solving Life's Problems: A 5-Step Guide to Enhanced Well-Being. New York: Springer Publishing Company.

Fisher, R. (1990). Teaching Children to Think. Cheltenham: Stanley Thornes Publishing. https://doi.org/10.1177/026565909000600105

Fiore, S. M., Cuevas, H. M., Scielzo, S. ve Salas, E. (2002). Training individuals for distributed teams: problem solving assessment for distributed mission research. Computers in Human Behavior, 18 (6), 729-744. https:/ / doi.org/10.1016/S0747-5632(02)00027-4

Fiore, S. M., Graesser, A., Greiff, S., Griffin, P., Gong, B., Kyllonen, P., ... ve Soulé, H. (2017). Collaborative Problem Solving: Considerations for the National Assessment of Educational Progress. Erişim adresi: https:// actnext.org/ research-and- 
projects/collaborative-problem-solving-considerations-for-the-nationalassessment-of-educational-progress /

Gözütok, F.D. (1994). İlkokul 1.2.3. Sınıf Hayat Bilgisi Dersi İhtiyaç Belirleme Araştırması [A Needs Assessment Research on Life Sciences Course for 1st,2nd and 3rd Grades in Primary Schools]. (Yayınlanmamış) Ankara.

Graesser, A. C., Dowell, N.ve Clewley, D. (2017). Assessing Collaborative Problem Solving Through Conversational Agents. In Innovative Assessment of Collaboration (pp. 65-80). Switzerland: Springer International Publishing. https://doi.org/10.1007/978-3-319-33261-1_5

Griffin, P., Care, E. ve McGaw, B. (2012). The Changing Role of Education and Schools. In Assessment and teaching of 21st century skills ( p.1-15). Springer, Dordrecht. https:/ / doi.org/10.1007/978-94-007-2324-5

Ireland, J. L. (2001). The relationship between social problem-solving and bullying behaviour among male and female adult prisoners. Aggressive Behavior: Official Journal of the International Society for Research on Aggression, 27(4), 297-312. https:/ / doi.org/10.1002/ab.1013

Johnson, D. ve Johnson, R. (1989). Cooperation and Competition: Theory and Research. Edina, MN: Interaction Book.

Karakuş, F. (2017). İlköğretim matematik öğretmeni adaylarının öğretimsel açıklamalara ilişkin tercihleri: sıfıra bölme konusu. Turkish Journal of Computer and Mathematics Education, 8(3), 352-377.

McCawley, P. F. (2009). Methods for conducting an educational needs assessment. University of Idaho, 23.

Milli Eğitim Bakanlığı, (2011). MEB 21. Yüzyıl Öğrenci Profili. Erişim adresi: http:// www.meb.gov.tr/earged/earged/21.\%20yy_og_pro.pdf.

Miles, M. B. ve Huberman, A. M. (1994). Qualitative Data Analysis: An Expanded Sourcebook (2nd ed.). Thousand Oaks, CA: Sage Publications.

Mulrey, B. C. (2017). Increasing Social Problem-Solving Skills in Early Childhood (Doctoral dissertation).New England College: New Hampshire.

Nebesniak, A. (2007). Using Cooperative Learning to Promote a Problem-Solving Classroom, Math in the Middle Institute Partnership. Action Research Project Report.

OECDb, P. I. S. A. (2017). Results in Focus, 2015.

Okazaki, M. ve Fujita, T. (2007, July). Prototype Phenomena and Common Cognitive Paths in the Understanding of the Inclusion Relations Between Quadrilaterals in Japan and Scotland. In Proceedings of the 31st Conference of the International Group for the Psychology of Mathematics Education (Vol. 4, pp. 41-48).

Parker, J. G. ve Asher, S. R. (1993). Friendship and friendship quality in middle childhood: links with peer group acceptance and feelings of loneliness and social dissatisfaction. Developmental psychology, 29 (4), 611. https:/ / doi.org/10.1037/0012-1649.29.4.611

Patton, M. Q. (2002). Qualitative Research and Evaluation Methods (3. basim). Thousand Oaks, CA: Sage Publications, Inc.

Pauli, R., Mohiyeddini, C., Bray, D., Michie, F. ve Street, B. (2008). Individual differences in negative group work experiences in collaborative student 
learning. Educational Psychology, 28(1), 47-58.

https:/ / doi.org/10.1080/01443410701413746

Polya, G. (1990). How to solve it? Princeton, NJ: Princeton University Press.

Richards, J. (2001). Needs Analysis. In Curriculum Development in Language

Teaching (Cambridge Language Education, pp. 51-89). Cambridge: Cambridge

University Press. https:// doi.org/10.1017/CBO9780511667220.005

Poore, S. (2008). Cooperative Learning in Relation to Problem Solving in the Mathematics Classroom. Math in the Middle Institute Partnership Action Research Projects.

Rojas-Drummond, S. ve Mercer, N. (2003). Scaffolding the development of effective collaboration and learning. International Journal of Education Research, 39, 99111. https:/ / doi.org/10.1016/S0883-0355(03)00075-2

Rosen, Y. (2015). Computer-based assessment of collaborative problem solving: exploring the feasibility of human-to-agent approach. International Journal of Artificial Intelligence in Education, 25(3), 380-406. https:/ / doi.org/10.1007/s40593-015-0042-3

Sava, S. (2012). Needs Analysis and Programme Planning in Adult Education. Budrich : Verlag Barbara. https:/ / doi.org/10.3224/86649481

Spradley, J. P. (1979). The Ethnographic Interview. New York: Harcourt Brace Jovanich College Publisher.

Storey, L. (2007). Doing Interpretative Phenomenological Analysis. In E. Lyons ve A. Coyle (Eds.). Analysing Qualitative Data in Psychology. (p. 51-64). Los Angeles: SAGE Publications https://doi.org/10.4135/9781446207536.d11

Tam, H. (2013). Cooperative Problem-Solving and Education. In FORUM: for promoting 3-19 comprehensive education (Vol. 55, No. 2, pp. 185-202). Symposium Books. PO Box 204, Didcot, Oxford, OX11 9ZQ, UK. https:/ / doi.org/10.2304/forum.2013.55.2.185

Ulusoy, F. ve Çakıroğlu, E. (2017). Ortaokul öğrencilerinin paralelkenarı ayırt etme biçimleri: aşırı özelleme ve aşırı genelleme. Abant İzzet Baysal Üniversitesi Ĕ̈itim Fakültesi Dergisi, 17(1), 457-475. https:/ / doi.org/10.17240/aibuefd.2017.17.28551-304648

UNESCO/APC (2013). Multimedia Training Kit Cooperative Problem Solving: A Guide for Turning Conflicts into Agreements. Erişim adresi: http://www.itrainonline.org/itrainonline/mmtk/mmtk_cps_handout.PDF

Watanabe, Y. (2006). A needs analysis for a Japanese high school efl general education curriculum. University of Hawai I Second Langauge Studies Paper 25, (1).

Way, J. (2011). Co-Operative Problem Solving: Pieces of the Puzzle Approach Stage: 1, 2, 3 and 4. Erişim adresi: https:/ / nrich.maths.org/2547

Wooldridge, M. ve Jennings, N. R. (1999). The cooperative problem-solving process. Journal of Logic and Computation, 9(4), 563-592. https:/ / doi.org/10.1093/logcom/9.4.563

Yaralı, K. T. ve Özkan, H. K. (2016). Çocukların (60-72 aylık) sosyal problem çözme becerileri ile sosyal yetkinlik ve davranış durumları arasındaki ilişkinin incelenmesi. Türkiye Sosyal Araştırmalar Dergisi, (2) 345-361.

Yasul, A. F. ve Samancı, O. (2015). Sınıf öğretmenlerinin grup çalışmalarına ilişkin görüşlerinin incelenmesi. Igdir University Journal of Social Sciences, (7), 131-156. 
Yeşilyurt, E. (2010). Öğretmen adayları niteliklerinin işbirliğine dayalı öğrenme yöntemine uygunluğunun değerlendirilmesi. Dicle University Journal of Ziya Gokalp Education Faculty, 14, 25-37.

Yıldırım, A. ve Şimşek, H. (2003). Sosyal Bilimlerde Nitel Araştırma Yöntemleri. Ankara: Seçkin Yayınları.

\section{Summary}

\section{Introduction}

In an educational environment, the need expresses that there is an educational gap or deficiency, and it includes the understanding, attitude and skills required to reach the desired situation (Atwood and Ellis, 1971). Needs analysis generally consists of gathering information, analyzing information and creating a curriculum. Adigüzel (2016) states that the first stage is the determination of the scope and features of the subject in the needs analysis, the second stage is the determination of the target audience, the location should be determined in the third stage and finally the time should be determined. In this context, it is important to determine the knowledge of students about cooperative problem solving, which has been used as a new concept in recent years, in order to conduct a needs analysis study on cooperative problem solving.

In the PISA 2015 evaluation report, it is stated that the problem solving skills of students in our country based on cooperation are quite low. The report states that the students in our country do not like group work and they are quite inadequate in solving a given problem as a team. However, according to the report, it is stated that students in Singapore score higher than students in all other participating countries, while Japan is in the second rank in collaborative problem solving. On average in OECD countries, only $28 \%$ of students can solve simple collaborative problems. However, in Estonia, Hong Kong, Japan, Korea, Macau and Singapore, fewer than six students show low success in cooperative problem solving. Across OECD countries, $8 \%$ of students perform best in collaborative problem solving. Compared to other countries, this shows that students in these countries are aware of group dynamics, adopt team spirit and act accordingly (OECD, 2017). The purpose of PISA is to examine how school information is transferred to daily life and how the connection is established. For our country it is considered important that students acquire collaborative problem solving skills and take place among other countries with this skill. Therefore, it is important to conduct a needs analysis study that includes student views on a collaborative problem solving curriculum to be prepared for the development of our country's collaborative problem solving skills.

\section{Method}

This study is a qualitative research that examines student views. Qualitative research enables the participant to discover subjective points of view regarding the events (Storey, 2007). In the present study, analytical approach was adopted. With the analytical approach, changes based on national and international conditions are carefully examined. In this context, the needs of the students are determined based on the possible situations that may arise in the future (Gözütok, 1994). The study group 
consists of 50 students and volunteering was taken into account in participation in the study. Study group consists of 12 students from fourth grade, 16 students from fifth grade, and 22 students from sixth grade. The participants were given codes such as S1, S2, S3.

\section{Results}

It was determined that the students' views on the concept of problem were gathered in four themes as result-oriented, social context, course content and negativity. Students thought that it was easier and more fun to solve the problem in the group of friends rather than solving the problem alone, and that they made efforts to find a common idea in this process. The opinions of students about the problem solving action were gathered under four themes such as achievement, effort, relaxation and neutral. It was also determined that the students were happy when solving problems with a group of friends and expressed that they care about their friends and their ideas. In the case of disagreement, students thought that everyone's opinion should be taken into consideration, and that if they had a dominant friend in the group, it would be effective to warn him.

\section{Discussion}

The students think that they solve problems faster with their friends. In this context, it can be said that students are happy to solve problems cooperatively and fulfill the assigned task more easily. It is stated in the literature that cooperative problem solving is more productive than individual problem solving activities and more suitable for problem solving. The reason for this is to reach a result that will satisfy all group members in the collaborative problem solving process (Wooldridge and Jennings, 1999). On the other hand, in collaborative problem solving, the student sees different opinions of his / her other friends and realizes in which ways he / she disagrees with them (Tam, 2013; Fiore et.al., 2017). In addition, in solving problems individually, the student will either suggest a limited number of solutions or cannot find a solution. However, in collaborative environments, there is a higher potential for more than one alternative way to solve a problem. Furthermore, the problem situation dealt with cooperative problem solving is solved faster than the assigned time when individual efforts are made. This rapid cooperation contributes to the group members to develop themselves individually (Clearwater, Huberman and Hagg, 1991).

\section{Araştırmanın Etik İzinleri}

Yapılan bu çalışmada "Yükseköğretim Kurumları Bilimsel Araştırma ve Yayın Etiği Yönergesi" kapsamında uyulması belirtilen tüm kurallara uyulmuştur. Yönergenin ikinci bölümü olan “Bilimsel Araştırma ve Yayın Etiğine Aykırı Eylemler” başlı̆̆ı altında belirtilen eylemlerden hiçbiri gerçekleştirilmemiştir.

Etik kurul izin bilgileri

Etik değerlendirmeyi yapan kurul ad1 =Afyon Kocatepe Üniversitesi Sosyal ve Beşeri Bilimleri Bilimsel Araştırma ve Yayın Etiği Kurulu

Etik değerlendirme kararının tarihi= 11.01.2019

Etik değerlendirme belgesi sayı numarası=92255297-604.01.01-E.794147 


\section{Authors' Biodata/ Yazar Bilgileri}

Gülçin KARAKUŞ Sivas Mustafa Kemal Atatürk Mesleki ve Teknik Anadolu Lisesinde İngilizce Öğretmeni olarak çalışmaktadır.

Gülçin Karakuş works as an English Teacher at Sivas Mustafa Kemal Atatürk Vocational and Technical High School.

Gürbüz OCAK Afyon Kocatepe Üniversitesi, Eğitim Fakültesi, Eğitim Bilimleri Bölümü, Eğitim Programları ve Öğretimi Anabilim Dal'ında Prof. Dr. olarak çalışmaktadır.

Gürbüz Ocak works as a Professor at Afyon Kocatepe University, Faculty of Education, Department of Curriculum and Teaching. 